\title{
Surfaces
}

\section{CULTURE AND THE HUMANITIES: SYMPTOMATOLOGIES, MOSTLY HISTORICAL, MAINLY GERMAN}

\section{K. Ludwig Pfeiffer}

Volume 4, 1994

CONFÉRENCE INTERNATIONALE SUR LE DISCOURS HUMANISTE

(PREMIÈRE RENCONTRE, 3-8 AVRIL, 1994)

INTERNATIONAL CONFERENCE ON HUMANISTIC DISCOURSE (FIRST

MEETING, APRIL 3-8, 1994)

URI : https://id.erudit.org/iderudit/1064970ar

DOI : https://doi.org/10.7202/1064970ar

Aller au sommaire du numéro

Éditeur(s)

Les Presses de l’Université de Montréal

ISSN

1188-2492 (imprimé)

1200-5320 (numérique)

Découvrir la revue

Citer cet article

Pfeiffer, K. (1994). CULTURE AND THE HUMANITIES: SYMPTOMATOLOGIES, MOSTLY HISTORICAL, MAINLY GERMAN. Surfaces, 4.

https://doi.org/10.7202/1064970ar
Résumé de l'article

Sur l'arrière-plan de l'herméneutique et du romantisme allemand, l'auteur trace les contours institutionnels, historiques et conceptuels de la notion de Geisteswissenschaften. Il élabore plus spécifiquement les conceptions de Kant, Fichte, von Humbolt et, plus longuement, les efforts que déploie Dilthey pour élaborer, à l'aide de la notion de Geist, une conception globale de la vie, de la théorie et des institutions. Il décrit ensuite le changement qui a permis à la notion de Kultur de succéder, au centre du débat, à celle de Geist.
Copyright @ K. Ludwig Pfeiffer, 1994

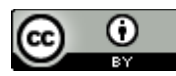

Ce document est protégé par la loi sur le droit d'auteur. L'utilisation des services d'Érudit (y compris la reproduction) est assujettie à sa politique d'utilisation que vous pouvez consulter en ligne.

https://apropos.erudit.org/fr/usagers/politique-dutilisation/ 
CULTURE AND THE HUMANITIES

SYMPTOMATOLOGIES, MOSTLY HISTORICAL, MAINLY GERMAN

\author{
$\underline{\text { K. Ludwig Pfeiffer }}$
}

\begin{abstract}
Against the backdrop of hermeneutics and German Romanticism, this essay traces the institutional, historical, and conceptual contours of the notion of Geisteswissenschaften. In this context, it concentrates on the conceptions of Kant, Fichte, von Humboldt, and, at greater length, on Dilthey's efforts to use a notion of Geist to meld together life, theory, and the institution. It then plots the transition from a concern with Geist to a concern with Kultur.
\end{abstract}

\title{
RÉSUMÉ
}

Sur l'arrière-plan de l'herméneutique et du romantisme allemand, l'auteur trace les contours institutionnels, historiques et conceptuels de la notion de Geisteswissenschaften. Il élabore plus spécifiquement les conceptions de Kant, Fichte, von Humbolt et, plus longuement, les efforts que déploie Dilthey pour élaborer, à l'aide de la notion de Geist, une conception globale de la vie, de la théorie et des institutions. Il décrit ensuite le changement qui a permis à la notion de Kultur de succéder, au centre du débat, à celle de Geist.

\section{The Humanities and/as Hermeneutics}

Romanticism, Cassirer has said, enveloped nature and history into a veil: the desire to know was "content with losing itself in sheer perceptual awe of the wellsprings of life"(9) -- or what seemed to be taken as such. Schelling's 
conception and its romantic extensions --"Nature is a poem, wrapped in secret and wondrous form", a Nature harboring "that marvelously deceptive odyssey of Spirit"(Cassirer 6) -- called for forms of emergent humanities only. This applies both to discourse (fascinated speculation about the relics or hidden pillars of enchantment in the modern world) and to institutionalization (a subsidiary existence of spiritual-hermeneutic consciousness within or on the borderlines of established and accepted disciplines like theology and classical philology). The Geisteswissenschaften start out as Geisteswissenschaft, as secularized, but still quasi-religious pneumatology (a term indeed still used, in J. E. Erdmann's history of German speculation since Kant in 1853, interchangeably with Geisteswissenschaft; Rothacker 6).

Traditionally, that is since the Middle Ages down to the 18th century, hermeneutics, in its different domains, had been practiced, with methodological rigor, in matters theological, reasonable (philosophy, history) or socially functionalized (law, history). The domains of culture -- domains not separated, but distinguishable from theological norms, philosophical reason and social practice -- had remained discursively implicit. They had been embedded in, and absorbed into, the self-evidence of classical values and the functionalization of 'history' for political purposes. Examples of that functionalization with incipient -- but only incipient - - -- institutionalization are provided by humanistic academies (sodalities) or Leibniz' proposals, made to the Hannoverian elector, for a historical institute (see Hammer/ Voss, eds.). Characteristically, though, "les sciences" relevant for the "honnête homme" -- "la Morale, la Politique et la connoissance des BellesLettres" (Saint-Evremond) were instruments for the intelligent conduct of life (cf. Hassinger).

Of course, there had 'always' been poetics and rhetoric. But their interests had been mainly prescriptive, their know- ledge, from Aristotle via Sidney to Dr. Johnson, of contemporary artistic production doubtful, sometimes blatantly insufficient. We may construct theoretical and aesthetic continuities (histories of criticism and the like). But in doing so, we lift a basic cultural (and probably anthropological: see Leroi-Gourhan or Victor Turner) need for and coupling of 'art' and its reception out of the manifold configurations into which social interests, media evolution and degrees of institutionalized consumption have variously coalesced.

Classical philology, in any case, given its long-term socio-cultural anchorage, had been able to conduct itself as rule-governed exegesis. In its standard forms, it remained exegesis, with its social values largely taken for granted, until far into the 19th century when, with Boeckh, it finally merged, at least terminologically, with hermeneutics. There had been, it is true, culturally more vehemently rumbling problems of exegesis: For the techniques of allegorization in later Greek and Hellenenistic times, the theologico-rational locus of Homer was at stake; for the quarrel between the ancients and the moderns (and its several predecessors and successors) questions of relative authority came to the forefront. But these had remained discursively, institutionally, 'regionally' controlled episodes. 
Romantic Geisteswissenschaft, on the other hand, whether or not in the wake of Schelling (Friedrich Ast, author of Grundlinien der Grammatik, Hermeneutik und Kritik, 1808, for one, was a disciple of Schelling), no longer behaving as grand speculation nor as classical philology taking the classical as the spiritual paradigm pure and simple, had to establish itself as non-exegetical hermeneutics. As such, and from the outset, it had a generalized and therefore vaguely conceptualized problem of culture on its hands. Institutionally, it mostly developed within and out of theology and classical philology. In terms of subject matter, it frequently limited itself, like Ast, to the Greek and Roman classics. But those were now seen under an explicitly cultural orientation: They are encoded, to some extent under the impact (misprision?) of Goethe, into representatives of a Spirit remote from a "frightening, forbidding [abschreckend] modern world" (quoted in Szondi 139). "In the auratic fog" (Szondi) of Spirit, all the problems resulting from the difference in 'time' between the ancients and the present are dissolved. Or so it seemed, for a while.

\section{Geisteswissenschaften or the Institutionalization of the Shadows of Shadows?}

To link a type of theory (like the philosophy of the spirit) with a slogan-like characterization of the times may appear as one of the worst short-circuits in the sociology of knowledge. Yet it is clear that W. von Humboldt pushed the "Philosophische Fakultät" (in which disciplines, never really at ease with each other, of potential cultural significance and sometimes even social usefulness, were henceforth yoked together) into the center of his reform university, because he could not see any other means of pulling Prussia, after Jena and Auerstedt, out of its desolate condition (see Lämmert 24-25, also for the analogous transformation of "Technische Hochschulen "into "Technische Universitäten" after World War II in Germany). And it is possible, in a more general vein, to interpret the new conceptions of the universities at the beginning of the 19th century (Engel, Ehrhard, Schleiermacher, Fichte, Humboldt) and their ruminations on the political and economic state of the world as the discursive pathway into the intrauniversity separation of the natural and 'practical' sciences from the humanities (see Müller 10-19, also for the following). While the former maintain relationships, however dubious, with the ways of the world, the latter must distinguish, define, and legitimize themselves by esoteric -scholarly, in Germany in fact 'scientific' -- gestures.

18th century (in some countries also 19th century) common-sense conceptions of universities, emphasizing the utilitarian links between the sciences on the one hand, administration, social legislation, 'cultivation' of agricultural and manufactural (!) resources -- in short: the imaginary greatest happiness of the greatest number (a socially defined Glückseligkeit) -- on the other hand, did not envisage any need for what, in Germany, finally came to be called Geisteswissenschaften. Kant, in his Streit der Fakultäten (1798), struck an extremely precarious balance. The 'upper' faculties (theology, law, medicine), although establishing themselves as reasonable sciences, also serve the purposes of the state. The lower faculty 
(philosophy), not serving any practical purposes, must (and for Kant indeed can) claim judgmental offices, through which, without a revolution, enlightenment can take place. In that sense Kant can accept the French Revolution while rejecting its model of the state. Today, the humanities are sometimes asked to develop a new social ethics and to evaluate technological advances -- or to further the causes of political correctness.

Kant was entrenched in an 18th century institutional and social framework. The discrepancies between that framework and the potential range of philosophical analysis did not erupt, for him, in any systematic way (they may have provoked some interactive peculiarities, or even pathologies; $\mathrm{cf}$. Böhme/Böhme).

Fichte, though, had grounds to cast the suspicion of general 'embourgeoisonnement' upon his time. Accordingly, in several lectures on the function of the philosopher-scholar (taken over, in somewhat different form, for the man of letters by Carlyle in England) and in his university plan, he staked exorbitant claims for a mythological creature: the philosopherscholar ("der Gelehrte") was conceived as the almost paradoxical fusion of person and institution (the ideal personality as an institution in one case, A. Gehlen). It is clear that a personalized institution of such stature could not really live and exert its cognitive power within the "ordinary university" ("gewöhnliche Universität"), composed as that one was of complex and heterogeneous disciplines and "irregular" (!) students. Therefore, Fichte envisaged an "academy" within the ordinary university, in which an elite of "regular" students were supposed to study and live together (clad in uniforms), continuously controlled, by their teachers, with respect to their intellectual-spiritual progress. This elite was supposed to be given priority when the highest offices of state were awarded.

The conceptions of Schleiermacher and Humboldt cut down the political claims (which, incidentally, drove Fichte to resign as the rector of the university of Jena, because he was not allowed to decide a duel case among students). Again, however, it must be remembered that Humboldt wanted to guarantee the freedom of research, that is, the autonomy properly defining the university, through university-owned and -managed estates. In spite of the central position of the "Philosophische Fakultät" in the university, he still entertained and promoted the idea of an academy which was to be granted the highest degree of independence from the state.

The demand, then, of a "knowledge of life", that is of matters not immediately practical and technical, a knowledge replacing the "sheer perceptual awe" of the Romantics (Cassirer), ran into a conceptual dead end once the vague spiritual transformation of the classics (Ast) was confronted by the needs of generalized institutional implementation within the new university conceptions. Pathetically and euphemistically, one can say, with Cassirer, that there was "a serious defect, an internal wound", that is, a lack of "inner unity" in the face of "all these triumphs of knowledge"(87) achieved in the disciplines devoted to the knowledge of life as the variously manifested life of the spirit. More grimly, one can speak of the "impossibility of the Geisteswissenschaften". It is owed, on a superficial level even, to the "deep heterogeneity" of the disciplines potentially and factually within their 
range (they may include anything from theology, philosophy, to law and literary and linguistic studies; cf. Kraft). For the 19th century, the institutionalization of the Geisteswissenschaften hides what Taine, in the absence of an emphatic concept of the spirit and in one of his nonscientistic, sceptical moods, diagnosed as a negative, modern version of Platonism: "The religious man lives for a shadow; but we live for the shadow of a shadow: what will those who come after us live for?"(quoted in Cassirer 31).

\section{Dilthey's Ghost}

The spirit (or Spirit) remained a short-lived conceptual joker. It did not reside in the disciplines devoted to it, but survived, as a conceptual ghost, in and through their institutionalization. The latter, given the late beginning, then the high speed of drastic socio-economic changes in Germany, became urgent in the late 19th century. Then, when capitalism became dreary, "flanking measures" (Claessens/Claessens) became urgent: Since higher, encompassing values no longer emerged from, or were embedded in the forms of life, they -- or at least their suggestion and halo -- had to be specifically fabricated. This is why, in spite of the postulated relation between experience ('Erleben', 'Leben'), expression, and understanding (e.g. VII, 86-87), an undefined no-man's-land stretches between Dilthey's notions of life and experience, on the one hand, and the labors of the Geisteswissenschaften, on the other. An autobiography may provide a model of how consciousness deals with life, because it mediates between the tensions of accumulated experience and distancing reflection (VII, 74, 204). But the Geisteswissenschaften preserve the spirit of life in the form of Bildung, a somewhat more petrified affair (to degenerate, after some more exciting interludes with Heidegger and others, into the Ausbildung or information, sometimes still called knowledge, of the later 20th century, or then into neuronal activity producing ideas of 'Geist' without embodying them). The internal heterogeneity of the Geisteswissenschaften turns into liabilities: While the representatives of some of them (like history, 'national' economy, constitutional law, to some extent theology) are inevitably involved into the life and ideological struggles of their times, others -- in particular the disciplines involved in interpreting the aesthetic highlights of the past (that is the monuments of culture in a now significantly restricted sense), have to simulate the participation in past forms of life through empathy (cf. VII, 137 and 213-14 for "Sichhineinversetzen", "Nachbilden", "Nacherleben"). In his Habilitationsschrift, significantly named Wirklicher und unwirklicher Geist (1931), Arnold Gehlen granted that Hegel -- and the mystics -- knew what the absolute spirit was. "But who dares to assert, today, to understand that"? (134) What remains is the strange spectacle of the Geisteswissenschaften, their vague and inconsequential ability to understand anything, their spreading out masses of historical-psychological literature which nobody really enjoys or suffers from (343). Gehlen looks for the real spirit in emphatically experienced situations with "high degrees of being" -- and, sometimes, to be sure, the Geisteswissenschaften were able to create them. Gadamer tells convincing stories about Nicolai Hartmann's peculiar charisma (the same Hartmann, though, who had great trouble, in his Das Problem des geistigen Seins, to distinguish among spirit, mass 
suggestion, public opinion, empty 'spiritual' trends, and habitualized selfdeception), about Heidegger's lectures, where topics tended to have a quasiphysical impact on the audience, and about his own interpretations of Rilke in the classroom, when the bombs were coming down on Leipzig (21-22, 118-122; incidentally, Gadamer was the successor of Gehlen in Leipzig). Yet: In 1989, Klaus Heinrich laments the 'Geistlosigkeit' of the universities (in particular of course of the disciplines devoted to Geist) which have locked out the "vital subject" $(10,15)$. One can read about that in novels like H. von Doderer' Die Dämonen ("the humanities departments of modern universities have little to do with those powers of the spirit which challenge the total human being", 203-04). What has remained, according to Musil, is a small mixed group of soul-searchers ("Seelenvolle"), fighters for the spirit ("Geistkämpfer"), and utilitarians (1047). If pneumatology after Hegel had to vanish quickly, since its religious basis could not be maintained, the spirit was soon to follow. Pseudo-concretizations like Volksgeist were undermined by their creators, like Herder, themselves: in contrast to them, notions like continuous change (described, for instance, later by Spencer as the change of systems) turned out to be more powerful (Koselleck has shown this for Herder).

Why, then, did Dilthey grasp for a theoretically consistent general concept ("Geisteswissenschaften"), in order to unify an incongruous array of disciplines? Dilthey, I suggest, was torn between demands of practical utility, scientific pressure, the pathos of life (in the sense outlined above with Gehlen), and the multifariousness of cultures. The modern state demanded utility; Dilthey tried to provide it, claiming, not implausibly, that, through the Geisteswissenschaften, the politician, the lawyer, the theologian, the teacher were put into a better position to locate their specialized concerns "in the comprehensive reality of human society" $(I, 3)$. There is, indeed, a necessity to "transcend the measure of a technical training", in which everybody is just a tiny part of the social machine, in order to take part in the shaping ("mitgestaltend") of that machine (ibid.). In the beginning (that is before the Einleitung in die Geisteswissenschaften of 1883), that transcendence, though, remains very close to the more concretely practical moral and political sciences (cf. vol. XVIII, in particular the editor's introduction, p. xiii). In fact, Dilthey will never get rid of the congeries of heterogeneous disciplines (from physiology to empirical psychology, to its speculative variants, and so on), in which the practical, the scientific, and the vaguely speculative have joined in an uneasy alliance. The disciplines have grown out, in variously rudimentary or elaborate forms, from the "practice of life": rhetoric and politics with the Greeks, instructions for priests and magistrates in Rome, resulting in the development of a legal discourse and a constitution...(I, 21-22, XX, 137-38; cf. the "almost chaotic" genetic picture in Rothacker, 3f.). But it is only in the 19th century that the separation ("Aussonderung") of these disciplines from the "historico-social reality" was felt to be necessary (I, 27). Seen from that vantage-point of social differentiation ("Differenzierungsprozeß der Gesellschaft" -- and that, indeed, was "life" in the 19th century, I, 39), former periods cannot claim to have developed institutionalized and theoretically clarified humanistic discourses. The second (and much longer) book of the first volume of the Einleitung is therefore devoted to the decay of metaphysics. From its ruin, its built-in, but peripheral fragments of humanistic discourse may be 
gathered and forged into into a new whole. In a lecture with the same title, also from 1883, Dilthey offers a rudimentary compromise for that: In modern life, there is a liberation, a relative independence of the "spiritual expressions of life within the systems of culture [!]". Yet there remains a sufficient coherence ("Zusammenhang") of spiritual life. For modern people, the unity of that life does not lie in a comprehensive context of concepts; it is satisfied in life itself, in which the totality of lived phenomena unfolds into "a harmonious whole". Most people do not feel the need to have that whole in concepts -- "neither Shakespeare, nor Raphael, neither Luther nor Beethoven felt it". But "approximatively", that unity of the modern world can also be reached conceptually (XX, 143f.) This, however, is exactly what Dilthey did not achieve. A second (or third) volume of the Einleitung did not appear.

\section{The Allurements of Culture}

Is there anything to be derived from this laborious detour? If the spirit has abdicated, will culture (or analogous concepts with whatever historical and connotational shifts) take its place in a better fashion?

For the late 19th century Germany, the transition from Geistes- to Kulturwissenschaften was preprogrammed. Dilthey had sensed a necessity in his last writings; Rickert had installed the Kulturwissenschaften explicitly; Cassirer's Logic of the Humanities is called Logik der Kulturwissenschaften in German. Did -- or does -- anything change?

In its emphasis on conspicuously aesthetic products (the 'arts', particularly literature: cf. Das Erlebnis und die Dichtung) Dilthey's Geisteswissenschaften paid toll to a trend in socio-cultural differentiation. Daniel Bell has described it as a disjunction of social realms (which, somewhat later, came to be described in terms of 'systems'). The main point here is that culture turned into a seeming sphere of its own, with the preeminently aesthetic embodiments of the spirit (in particular literature), at its center. Ben Knights has noted that high verbality, centering in and around literature, became the main prerequisite for the clerisy, the "men of letters" in the 19th century, who were reticent about music, dismisissive at times of dancing and the visual or the so-called popular arts. "Within the intellectual hierarchy, not only non-verbal modes of communication [this is not quite true of Dilthey, who acknowledged them, but at the same time hauled them back into verbalization, with literature as its paradigm], but also the varieties of experience that cannot be or can be only tangentially verbalised are tacitly demoted to an inferior position" (225). Aesthetic, in particular then literary embodiments were not just defined in terms of specialized artistic procedures and techniques (that of course had always been the case), but in their increased 'symbolic' distance from socioeconomic production and ordinary forms of life. In the educated bourgeoisie, that distance was hidden for a while. But Dilthey himself was plagued by forebodings of the 'loneliness' of the Geisteswissenschaften producing 
powerless, motivationally weak, in short: mere ideas (cf. Schelsky 211-13). It is because of their weakness, not in spite of it, that they can be, and have been, violently 'repoliticized'. Whereas, from Marx to Baudrillard, the dominant dynamics of the 19th century consists in an overwhelming socioeconomic mode ('production'), the cultural mode has to assert itself primarily as artistic syncretism and interpretive-identificational simulation. This is why the installation of the Geisteswissenschaften is followed, rather quickly, by "the tragedy of culture" -- for Cassirer "a point of extreme sensitivity" (185). The goods created by intellectual development, especially in its institutionalized form, grow tremendously in number. In that growth, they tend to lose their value for us, because they do not turn into a "living possession" (185). Simmel's Philosophische Kultur (1911) is haunted with the image of an ego whose productions belong to "other worlds". These refuse to be united with those of the ego (Cassirer 186-87). The tragedy of culture may be pushed into the background: the privileging of literature and literarizing languages, in particular the philological verbalism (Kraft) of the humanities, surrounds everything with "a gigantic halo of discourse" (Butor), suggests interpenetrating, if not common horizons of significance. That way, canons of culture may be established, histories of culture carriers, like literature, may be written. Yet it remains difficult to escape Nietzsche's negative dialectic

Does not each culture want to take the single human being out the pushing and pulling, the crushing impact of the historical flow in order to make that being understand that $\mathrm{s} /$ he is not just a historically limited, but also a totally extrahistorical-infinite being with which all existence began and will stop? I do not want to believe that something which creeps, with dismal industry, through life, learns, calculates, politicizes, reads books, produces children and lies down to die -- that this is the human being [...].

But Nietzsche, of course, knew that carriers and media of that emphatic concept of culture are difficult to establish: "There is always a trend toward / pp. 14-15/

a sort of straying culture which, having lost its way and befriending the world of becoming, zealously tries to enclose human beings into the domains of their historical existence. Culture then is precisely supposed to liberate the spiritual powers of a generation to such an extent that it may become most useful for the existing institutions, the state, commerce and traffic, Church and society" (Fragments, Spring/ Summer 1874, 813, in the Colli/ Montinari edition, vol. 7).

\section{Perspectives: Between/Beyond Transcendentalizing and Empiricist Drifts}

In the limited, yet hopefully symptomatological stories meandering between conceptualizations and institutionalizations, an uncomfortable alternative seems to loom large for humanistic discourses: petrification or short-lived leaps into existential (aestheticist, political...) idealism. Petrification implies cultural obsolescence; existentialist, aestheticist, or politicizing leaps 
illustrate Nietzsche's characterization of l'art pour l'art as the virtuoso croaking of frogs, left out in the cold and despairing in their swamps.

Humanistic discourses are, paradoxically, necessary luxuries. Their concerns are -- varying historically, but sometimes also simultaneously -- matters of urgency and indifference. In spite of what some utilitarians and technologists have said and will say, an exteriorization of ourselves into cultural media and shapes has always taken place (for that, see in particular Leroi-Gourhan). This is why McLuhan spoke about media (more traditionally cultural or more radically technological) as extensions of ourselves (even if, of course, he or nobody could say what these selves, 'in themselves', consist of). Exteriorization breeds interpretation. The institutionalization of layers of discourse for that, however, always goes too far. More specifically, discourses of legitimization stand only tenuous chances of holding their own; deficits in the theoretical cogency and consistency of methodological and disciplinary organization have to be taken for granted anyway. Looking back on past efforts to mend these shortcomings, one is struck by the the combination of scepticism and optimism (not to say brazenness) displayed (e.g. Rothacker 112: The Geisteswissenschaften do have a systematic structure, but are not located in any system, because they are, in themselves, as contradictory as life itself).

One would need, paraphrasing Rothacker, attractive disguises of productive postulates (137, cf. 3-5). For more than a century, attractive disguises may have consisted in transforming/ transfiguring the technology of print, its preferential medium (the book), cognitive specialties (discourses of interpretation and theory), and forms of institutionalization (disciplines) into cultural values themselves. If it has taken a lot of experience - - -- the experience of cultural crisis as a consciousness of discrepancies and conflicts to be repaired at least symbolically -- for awakening interest in literary history or theory (cf. Rothacker 3-4), then such kinds of interest may show up in very different ways. Symptomatic discrepancies, indeed, show up within the range of humanistic discourses itself. They are, we may well surmise, due to media qualities and modes of production (film and its 'interpretation') or to the cognitive shifts in interpretive and performative tensions (opera and its tremendous span between meaninglessness, anthropological import and ideology). Thus, while the distinction between culturally marginal and central performances and discourses, is, in principle, itself a marginal one, it may become central once historical configurations can be specified (which is not always the case). That may mean, for instance, that the attention paid to a type of cultural object like 'literature' during the last 100 years cannot be paradigmatic, or only in a very limited sense. It does not exhaust behavioral and discursive potentials with respect to objects defined in some way as literary; nor does it envisage other forms of aesthetic behavior with respect to other 'media'; nor does it, finally, enable us to see the dynamic interrelationships of media in roughly defined cultural situations. That would mean a calculated dispersion, for instance, of 'reading' techniques (envisaged, in various ways by de Certeau, Deleuze/Guattari and others), but not a generalized deconstructive enterprise. It would mean (not just in a 'romantic' vein, but taking up some threads in Murray Krieger's Arts on the Level) a breaking of the monopoly of the ([w]holistically seen) work of art and a more pointed focus on the 
performative dimensions of culture. This would include the performances of humanistic discourse themselves, but, again, not warrant a generalized identification of these discourses with/as art. And it would finally mean, institutionally, to reduce the interpretational treatment of separated and nationalized arts (the term 'media' in spite of its contemporary trivialization, is probably better, because it does not mislead so much historically) by various styles of devotion to types of cultural configurations.

\section{K. Ludwig Pfeiffer}

\section{sprach - und Literaturwissenschaften}

\section{Universität Gesamthochschule Siegen}

\section{Works Cited}

Böhme, Hartmut, and Gernot Böhme. Das Andere der Vernunft. Zur Entwicklung von Rationalitätsstrukturen am Beispiel Kants. Frankfurt am Main: Suhrkamp, 1983.

Ernst Cassirer. The Logic of the Humanities , trans. Clarence Smith Howe. New Haven and London: Yale University Press, 1960.

Claessens, Dieter, and Karin Claessens. Kapitalismus als Kultur. Entstehung und Grundlagen der bürgerlichen Gesellschaft . Frankfurt am Main: Suhrkamp, 1979.

Dilthey, Wilhelm. Gesammelte Schriften. Göttingen: Vandenhoeck \& Ruprecht, 1959ff. [vols. I-XII in cooperation with B. G. Teubner, Stuttgart].

Doderer, Heimito von. Die Dämonen. München: Deutscher Taschenbuch Verlag, 1985 [1956].

Gadamer, Hans-Georg. Philosophische Lehrjahre - Eine Rückschau. Frankfurt am Main: Suhrkamp, 1977.

Gehlen, Arnold. Wirklicher und unwirklicher Geist. Philosophische Schriften, vol. I, ed. Lothar Samson. Frankfurt am Main: Klostermann, 1978.

Hammer, Karl, and Jürgen Voss, eds. Historische Forschung im 18. Jahrhundert. Bonn: Röhrscheid, 1976

Hassinger, Erich. Empirisch-rationaler Historismus. Seine Ausbildung in der Literatur Westeuropas von Guicciardini bis Saint-Evremond. Bern: Francke, 1978.

Heinrich, Klaus. "Zur Geistlosigkeit der Universität heute". Das Argument 173 (1989): 9-19.

Knights, Ben. The Idea of the Clerisy in the Nineteenth Century. Cambridge: Cambridge University Press, 1978. 
Kraft, Julius. Die Unmöglichkeit der Geisteswissenschaft. Hamburg: Meiner 1934, 3rd ed. 1977.

Leroi-Gourhan, André. Le geste et la parole, 2 vols. Paris: Albin Michel, 1964-65.

Müller, Ernst. "Geschäftsleute, Staatsmänner, Gelehrte - zur historischen Perspektivierung ihres Widerstreits". Müller, Pfeiffer, Wagner, eds. 9-20

Müller, Ernst, Pfeiffer, K. Ludwig, and Benno Wagner, eds. Geisteswissen. Vom wissenschaftspolitischen Problem zur problemorientierten Wissenschaft. Frankfurt am Main: Verlag für akademische Schriften, 1991.

Musil, Robert: Der Mann ohne Eigenschaften. Gesammelte Werke, vol. $1 \mathrm{ff}$. Reinbek bei Hamburg: Rowohlt, 1978.

."Geist und Erfahrung. Anmerkung für Leser, welche dem Untergang des Abendlandes entronnen sind". Gesammelte Werke, vol. 8. Reinbek bei Hamburg: Rowohlt, 1978. 1042-1059.

Pfeiffer, K. Ludwig. "Problemgeschichten". Müller/Pfeiffer/ Wagner, eds. 129-146.

Rothacker, Erich. Logik und Systematik der Geisteswissenschaften. München: Oldenbourg, 1965 [1927].

Schelsky, Helmut. Einsamkeit und Freiheit. Idee und Gestalt der deutschen Universität und ihrer Reformen. Reinbek: Rowohlt, 1963.

Szondi, Peter. Einführung in die literarische Hermeneutik. Frankfurt am Main: Suhrkamp, 1975.

\section{Surface Page d'Acceuil/Home Page}

